\title{
Cytotoxic anthrasteroid glycosides, malsterosides A-C, from Malbranchea filamentosa
}

\author{
Daigo Wakana ${ }^{1,2}$, Takeshi Itabashi ${ }^{1}$, Ken-ichi Kawai ${ }^{1}$, Takashi Yaguchi ${ }^{3}$, Kazutaka Fukushima ${ }^{3}$, \\ Yukihiro Goda ${ }^{2}$ and Tomoo Hosoe ${ }^{1}$
}

The Journal of Antibiotics (2014) 67, 585-588; doi:10.1038/ja.2014.43; published online 7 May 2014

Malbranchea species belong to the family Onygenaceae and are taxonomically close to human and animal pathogenic fungi. ${ }^{1}$ The fact prompted us to investigate the chemical constituents of Malbranchea fungi. We already have reported the isolation and structural characterization of 4-benzyl-3-phenyl-5 $\mathrm{H}$-furan-2-one as a vasodilator, malfilanols $\mathrm{A}$ and $\mathrm{B}$ as antifungal and cytotoxic sesquiterpenes, malbrancheosides $\mathrm{A}-\mathrm{D}$ as triterpene glycosides and malfilamentosides $\mathrm{A}$ and $\mathrm{B}$ as furanone glycosides, from the fungus Malbranchea filamentosa IFM41300..$^{2-5}$ Further purification of extracts of rice cultivated by the above fungus allowed us to isolate three new cytotoxic anthrasteroid glycosides, designated malsterosides A (1), B (2) and C (3) (Figure 1). This paper deals mainly with the structure determination and cytotoxic activity of 1-3.

The fungus M. filamentosa Sigler and Carmichael IFM41300 was provided from Medical Mycology Research Center, Chiba University in Japan.

The fungus was cultivated on moisturized rice $(1120 \mathrm{~g}$ ) using 8 Roux flasks (Kimura laboratory glass, Tokyo, Japan) at $25^{\circ} \mathrm{C}$ for 21 days. The cultivated rice was extracted with methanol after extracted with acetone and the solvent was evaporated in vacuo. The residue was chromatographed on DIAION HP20 (Mitsubishi chemical, Tokyo, Japan) with $\mathrm{H}_{2} \mathrm{O}, 20 \% \mathrm{MeOH}, 40 \% \mathrm{MeOH}, 60 \% \mathrm{MeOH}$, $80 \% \mathrm{MeOH}, \mathrm{MeOH}$ and acetone, in turn. The evaporated acetone elute was purified by centrifugal partition chromatography (Senshu Scientific, Tokyo, Japan) using the solvent system of $\mathrm{CH}_{2} \mathrm{Cl}_{2}-\mathrm{MeOH}-$ $\mathrm{H}_{2} \mathrm{O}$ (5:6:4) to obtain seven fractions. The second fraction $(169 \mathrm{mg}$ ) was purified using HPLC on ODS-4 $(5 \mu \mathrm{m}, 10 \times 250 \mathrm{~mm}$, GL Sciences, Tokyo, Japan) (70\% $\mathrm{MeOH}, \mathrm{CH}_{3} \mathrm{CN}-\mathrm{MeOH}-\mathrm{H}_{2} \mathrm{O}$ (7:7:6), in turn) to obtain malsteroside B (2: $10 \mathrm{mg})$ and malsteroside C (3: $30 \mathrm{mg})$. The sixth fraction was purified using HPLC on ODS-4 $(85 \%$ $\mathrm{MeOH})$ and Inertsil SIL $100 \mathrm{~A}(5 \mu \mathrm{m}, 10 \times 250 \mathrm{~mm}$, GL Sciences $)$ $\left(\mathrm{CH}_{2} \mathrm{Cl}_{2}-\mathrm{MeOH}(7: 1)\right)$ to obtain malsteroside A (1: $\left.37 \mathrm{mg}\right)$.

Malsteroside A (1) was obtained as a colorless crystalline powder (m.p. $129.5^{\circ} \mathrm{C}$ from $\mathrm{MeOH}$ ); molecular formula $\mathrm{C}_{34} \mathrm{H}_{52} \mathrm{O}_{7}$ by direct ion analysis in real time-time of flight-MS $\left(\mathrm{m} / \mathrm{z}: 573.3762[\mathrm{M}+\mathrm{H}]^{+}\right.$, calculated for $\mathrm{C}_{34} \mathrm{H}_{53} \mathrm{O}_{7}, \mathrm{~m} / \mathrm{z}$ : 573.3791$) ;[\alpha]_{\mathrm{D}}^{20}-12^{\circ}($ c 1.0, MeOH);
UV $\lambda_{\max } \mathrm{nm}(\log \varepsilon): 263.5$ (3.47), 254.5 (3.46), 227.0 (sh, 4.07), 213.0 (4.29); IR $v_{\max }^{\mathrm{ATR}} \mathrm{cm}^{-1}: 3360,1650,1450 .{ }^{1} \mathrm{H}-\mathrm{NMR}$ spectrum showed three singlet methyl protons $(\delta 0.43, \delta 1.80$ and $\delta 2.06)$, three doublet methyl protons $(\delta 0.78(\mathrm{~d}, 7.0), \delta 0.85(\mathrm{~d}, 6.7)$ and $\delta 0.92(\mathrm{~d}, 6.9))$, two methine protons $(\delta 5.34(\mathrm{~d}, 9.3), 6.56(\mathrm{~s}))$, nine oxygenated protons including an anomeric proton $(\delta 4.54$ (bs)) (Table 1). ${ }^{13} \mathrm{C}$-NMR spectrum showed 6 methyl carbons, $8 \mathrm{sp}^{3}$ methylene carbons including an oxygenated methylene $(\delta 62.5), 11 \mathrm{sp}^{3}$ methine carbons, 6 of which were bearing oxygen functions $(\delta 67.9, \delta 68.9$, $\delta$ 72.7, $\delta 75.3, \delta 77.8$ and $\delta 79.7)$ and 1 of which was anomeric carbon $\left(\delta\right.$ 100.9), an $\mathrm{sp}^{3}$ quaternary carbon $(\delta 44.1), 2 \mathrm{sp}^{2}$ methine carbons ( $\delta 124.5$ and $\delta 126.2)$ and $6 \mathrm{sp}^{2}$ quaternary carbons (Table 1$)$. The contiguous 2D-INADEQUATE correlations from C-1 to C-21, C-22 to C-28 and C-1 $1^{\prime}$ to $C^{\prime}-6$ of 1 suggested that structure of $\mathbf{1}$ consisted of a hexose moiety, a $1(10 \rightarrow 6)$ abeo-5,7,9-androstatriene skeleton and a 2,3-dimethylpentane unit (Figure 2a). The HMBC correlations from $21-\mathrm{H}_{3}$ to $\mathrm{C}-22$ suggested that C-20 position of the tetracyclic structure and $\mathrm{C}-22$ position of side chain were linked by a carbon double bond, and $1^{\prime}-\mathrm{H}$ to $\mathrm{C}-23$ also suggested that the C-1 position of sugar was attached to $\mathrm{C}-23$ position of side chain in ether linkage. These results suggested that $\mathbf{1}$ was an anthrasteroid monoglycoside, which should be rearranged such that the C-1-C-10 linkage of ergostane skeleton cleavaged, followed by the C-1-C-6 linkage was newly formed by ring-closing reaction. The relative stereochemistry of $\mathbf{1}$ was confirmed by the analysis of ROESY spectrum (Figure $2 \mathrm{~b}$ ). The ROESY correlations between the methyl group of $18-\mathrm{H}_{3}$ and methine proton of $16 \alpha-\mathrm{H}$, between the methine proton of $14-\mathrm{H}$ and the methine proton of $16 \beta-\mathrm{H}$ and $17-\mathrm{H}$ suggested that the stereochemistry between $\mathrm{C}$ and $\mathrm{D}$ ring was trans-form, and two protons of $14-\mathrm{H}$ and $17-\mathrm{H}$ were on same side. The geometric position at olefinic bond of C-20 and C-22 was confirmed to E-configuration by the ROESY correlations from $21-\mathrm{H}_{3}$ to $18-\mathrm{H}_{3}$ and $23-\mathrm{H}$, and from $22-\mathrm{H}$ to $28-\mathrm{H}_{3}$. Acid hydrolysis of $\mathbf{1}$ gave the sugar moiety of $\mathbf{1}$, but the genin could not be obtained for the production of complicated compounds unfortunately. The sugar moiety was determined D-mannose as by the comparison to commercial chemical with

${ }^{1}$ Faculty of Pharmaceutical Science, Hoshi University, Tokyo, Japan; ${ }^{2}$ Division of pharmacognosy, phytochemistry and narcotics, National Institute of Health Sciences (NIHS), Tokyo, Japan and ${ }^{3}$ Medical Mycology Research Center (MMRC), Chiba University, Chiba, Japan

Correspondence: Professor T Hosoe, Faculty of Pharmaceutical Science, Hoshi University, 2-4-41 Ebara, Shinagawa-ku, Tokyo 142-8501, Japan.

E-mail: hosoe@hoshi.ac.jp

Received 14 January 2014; revised 5 March 2014; accepted 19 March 2014; published online 7 May 2014 
${ }^{1} \mathrm{H}-\mathrm{NMR}$ spectrum and the value of $[\alpha]_{\mathrm{D}}$ (D-mannose, $+15.3^{\circ}$ $\left(\mathrm{H}_{2} \mathrm{O}\right)$ ). The glycoside linkage of D-mannose in $\mathbf{1}$ was confirmed to $\beta$-anomer from the ROESY correlation between $1^{\prime}-\mathrm{H}$ and $5^{\prime}-\mathrm{H}$. Given that biosynthetic intermediate of $\mathbf{1}$ is an ergosterol, it is

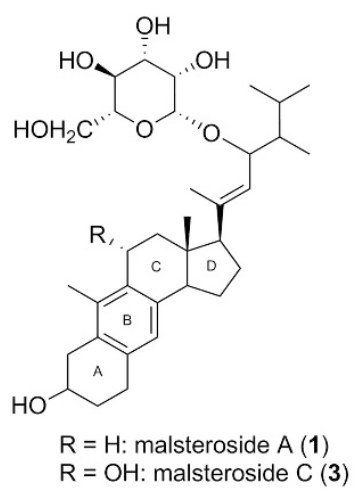

supposed that the stereochemistry of C-13 and C-17 is ' $R$ ' and ' $R$ ' configuration, respectively.

Malsteroside B (2) was obtained as a colorless crystalline powder: molecular formula $\mathrm{C}_{42} \mathrm{H}_{65} \mathrm{NO}_{12}$ by direct ion analysis in real time-time of flight-MS $\left(\mathrm{m} / \mathrm{z}: 776.4615[\mathrm{M}+\mathrm{H}]^{+}\right.$, calculated for 776.4585); $[\alpha]_{\mathrm{D}}^{20}+56^{\circ}\left(\right.$ c 1.0, MeOH); UV $\lambda_{\max } \mathrm{nm}(\log \varepsilon): 271.0$ (3.14), 249.0 (3.03), 226.5 (sh, 3.93); m.p. $160.8^{\circ} \mathrm{C}$ (from MeOH); IR $v_{\max }^{\mathrm{ATR}} \mathrm{cm}^{-1}: 3330,1645,1550,1430$. Malsteroside B (2) showed two anomeric protons $(\delta 4.54$ (bs) and $\delta 5.07(\mathrm{~d}, 3.7))$ in the ${ }^{1} \mathrm{H}-\mathrm{NMR}$ spectrum (Table 1 ), and the contiguous ${ }^{1} \mathrm{H}-{ }^{1} \mathrm{H}$ COSY correlations from $1^{\prime}-\mathrm{H}$ to $6^{\prime}-\mathrm{H}_{2}$ and $1^{\prime \prime}-\mathrm{H}$ to $6^{\prime \prime}-\mathrm{H}_{2}$ of 2 . Therefore, malsteroside B (2) should be a diglycoside. Observation of HMBC correlations from $1-\mathrm{H}^{\prime \prime}$ to $\mathrm{C}-5^{\prime \prime}$ and from $2^{\prime \prime}-\mathrm{H}$ to carbonyl carbon of acetylated group, NOESY correlation between $3^{\prime \prime}-\mathrm{H}$ and $5^{\prime \prime}-\mathrm{H}$, and the $J$ value of $11.0 \mathrm{~Hz}$ between $2^{\prime \prime}-\mathrm{H}$ and $3^{\prime \prime}-\mathrm{H}$ and between $3^{\prime \prime}-\mathrm{H}$ and $4^{\prime \prime}-\mathrm{H}$ in 2 suggested that one sugar contained within 2 was $\mathrm{N}$-acetyl-D-glucosamine (Figure 3). Acid hydrolysis of 2 gave one sugar and complicated decomposed products. This sugar was determined D-mannose from the comparison with its standard chemical. $\mathrm{N}$-acetyl-D-glucosamine, which was another sugar

Figure 1 Structure of malsterosides A (1)-C (3).

Table $1{ }^{1} \mathrm{H}$ - and ${ }^{13} \mathrm{C}$-NMR data of malsterosides A (1)-C (3) in methanol- $d_{4}$

\begin{tabular}{|c|c|c|c|c|c|c|}
\hline \multirow[b]{2}{*}{ Atom } & \multicolumn{2}{|r|}{ Malsteroside A (1) } & \multicolumn{2}{|r|}{ Malsteroside B (2) } & \multicolumn{2}{|r|}{ Malsteroside C (3) } \\
\hline & $\delta_{C}$ & $\delta_{H}(J$ in $H z)$ & $\delta_{C}$ & $\delta_{H}(J$ in $H z)$ & $\delta_{C}$ & $\delta_{H}(J$ in $H z)$ \\
\hline 1 & 29.3 & $2.72 \mathrm{~m}, 2.83 \mathrm{~m}$ & 27.6 & $2.67 \mathrm{~m}, 2.84 \mathrm{~m}$ & 28.8 & $\begin{array}{c}2.76 \mathrm{ddd}(5.4,9.7,16.6) \\
2.87 \mathrm{td}(5.5,16.6)\end{array}$ \\
\hline 2 & 32.4 & $1.64 \mathrm{~m}, 1.97 \mathrm{~m}$ & 27.8 & $1.80 \mathrm{~m}, 1.90 \mathrm{~m}$ & 31.9 & $1.66 \mathrm{~m}, 1.97 \mathrm{~m}$ \\
\hline 3 & 68.9 & $3.99 \mathrm{~m}$ & 74.0 & $4.11 \mathrm{~m}$ & 68.5 & $4.04 \mathrm{~m}$ \\
\hline 4 & 37.3 & $\begin{array}{l}2.45 \text { dd }(8.2,16.2) \\
2.98 d d(5.4,16.2)\end{array}$ & 35.3 & $2.71 \mathrm{~m}, 2.99 \mathrm{dd}(4.7,16.4)$ & 37.0 & $2.47 \mathrm{dd}(7.8,16.4), 2.99 \mathrm{~m}$ \\
\hline 5 & 131.1 & - & 131.0 & - & 132.4 & - \\
\hline 6 & 133.5 & - & 133.9 & - & 135.8 & - \\
\hline 7 & 124.5 & $6.56 \mathrm{~s}$ & 124.6 & $6.58 \mathrm{~s}$ & 124.2 & $6.61 \mathrm{~s}$ \\
\hline 8 & 138.3 & - & 138.5 & - & 138.9 & - \\
\hline 9 & 132.2 & - & 132.6 & - & 134.1 & - \\
\hline 10 & 134.6 & - & 135.0 & - & 137.4 & - \\
\hline 11 & 26.7 & $2.64 \mathrm{~m}, 2.77 \mathrm{dd}(7.8,17.7)$ & 26.7 & $2.65 \mathrm{~m}, 2.78 \mathrm{dd}(7.5,17.5)$ & 67.7 & $5.07 t(7.6)$ \\
\hline 12 & 37.6 & $1.67 \mathrm{~m}, 2.11 \mathrm{~m}$ & 37.9 & $1.71 \mathrm{~m}, 2.13 \mathrm{~m}$ & 49.7 & $\begin{array}{l}1.77 \mathrm{dd}(6.8,12.8) \\
2.61 \mathrm{dd}(8.5,12.8)\end{array}$ \\
\hline 13 & 44.1 & - & 44.6 & - & 47.3 & - \\
\hline 14 & 52.0 & $2.68 m$ & 52.6 & $2.72 \mathrm{~m}$ & 51.4 & $2.97 \mathrm{~m}$ \\
\hline 15 & 25.2 & $1.56 \mathrm{~m}, 2.11 \mathrm{~m}$ & 25.3 & $1.59 \mathrm{~m}, 2.13 \mathrm{~m}$ & 25.5 & $1.61 \mathrm{~m}, 2.14 \mathrm{~m}$ \\
\hline 16 & 26.4 & $1.86 \mathrm{~m}, 2.08 \mathrm{~m}$ & 26.5 & $1.88 \mathrm{~m}, 2.07 \mathrm{~m}$ & 26.0 & $1.86 \mathrm{~m}, 2.03 \mathrm{~m}$ \\
\hline 17 & 59.3 & $2.24 \mathrm{t}(9.6)$ & 59.6 & $2.26 t(9.3)$ & 59.7 & 2.38t (9.6) \\
\hline 18 & 12.8 & $0.43 \mathrm{~s}$ & 12.8 & $0.43 \mathrm{~s}$ & 14.1 & $0.33 \mathrm{~s}$ \\
\hline 19 & 15.0 & $2.06 \mathrm{~s}$ & 14.7 & $2.06 \mathrm{~s}$ & 15.6 & $2.27 \mathrm{~s}$ \\
\hline 20 & 139.1 & - & 139.5 & - & 139.0 & - \\
\hline 21 & 20.0 & $1.80 \mathrm{~s}$ & 19.7 & $1.81 \mathrm{~s}$ & 19.8 & $1.82 \mathrm{~s}$ \\
\hline 22 & 126.2 & $5.34 d(9.3)$ & 126.5 & $5.34 d(9.7)$ & 126.5 & $5.34 d(9.4)$ \\
\hline 23 & 79.7 & 4.42dd $(7.5,9.3)$ & 79.7 & $4.43 \mathrm{dd}(7.3,9.1)$ & 79.6 & 4.43dd $(7.8,9.2)$ \\
\hline 24 & 44.4 & $1.56 \mathrm{~m}$ & 44.5 & $1.55 \mathrm{~m}$ & 44.4 & $1.57 \mathrm{~m}$ \\
\hline 25 & 28.5 & $1.93 \mathrm{~m}$ & 28.8 & $1.93 \mathrm{~m}$ & 28.6 & $1.93 \mathrm{~m}$ \\
\hline 26 & 17.8 & $0.85 d(6.7)$ & 17.8 & $0.85 d(6.5)$ & 17.9 & $0.85 d(6.8)$ \\
\hline 27 & 22.1 & $0.92 \mathrm{~d}(6.9)$ & 22.0 & $0.92 d(6.6)$ & 22.1 & $0.92 \mathrm{~d}(6.8)$ \\
\hline 28 & 10.7 & $0.78 d(7.0)$ & 10.6 & $0.77 d(7.3)$ & 10.7 & $0.77 d(7.1)$ \\
\hline $1^{\prime}$ & 100.9 & $4.54 \mathrm{bs}$ & 101.0 & $4.54 \mathrm{bs}$ & 100.9 & $4.54 \mathrm{bs}$ \\
\hline $2^{\prime}$ & 72.7 & 3.83d (3.2) & 72.8 & 3.83bd (3.6) & 72.7 & 3.83d (3.2) \\
\hline $3^{\prime}$ & 75.3 & $3.42 \mathrm{dd}(3.2,9.5)$ & 75.6 & $3.41 \mathrm{dd}(3.6,9.3)$ & 75.3 & $3.42 \mathrm{dd}(3.2,9.5)$ \\
\hline $4^{\prime}$ & 67.9 & $3.63 t(9.5)$ & 68.3 & $3.63 t(9.3)$ & 68.0 & $3.62 \mathrm{t}(9.5)$ \\
\hline $5^{\prime}$ & 77.8 & $3.13 d d d(2.6,4.5,9.5)$ & 78.1 & 3.14ddd $(2.8,3.6,9.3)$ & 77.8 & $3.15 d d d(2.6,4.6,9.5)$ \\
\hline $6^{\prime}$ & 62.5 & $3.74 d d(4.6,11.6), 3.81 d d(2.6,11.6)$ & 62.7 & $3.74 \mathrm{~m}, 3.80 \mathrm{~m}$ & 62.6 & $3.74 d d(4.6,11.7), 3.82 d d(2.6,11.7)$ \\
\hline $1^{\prime \prime}$ & & & 96.5 & $5.07 \mathrm{~d}(3.7)$ & & \\
\hline $2^{\prime \prime}$ & & & 55.7 & $3.86 \mathrm{dd}(3.7,11.0)$ & & \\
\hline $2^{\prime \prime}-\mathrm{NHCOCH}_{3}$ & & & 173.6 & - & & \\
\hline $2^{\prime \prime}-\mathrm{NH}^{\mathrm{C} O C \mathrm{CH}_{3}}$ & & & 22.6 & $1.97 \mathrm{~s}$ & & \\
\hline $3^{\prime \prime}$ & & & 74.0 & $3.64 t(11.0)$ & & \\
\hline $4^{\prime \prime}$ & & & 72.6 & $3.75 \mathrm{~m}$ & & \\
\hline $5^{\prime \prime}$ & & & 72.4 & $3.33 \mathrm{~m}$ & & \\
\hline $6^{\prime \prime}$ & & & 62.7 & $3.66 \mathrm{~m}, 3.77 \mathrm{~m}$ & & \\
\hline
\end{tabular}


part of 2, was not detected in hydrolysate of 2. The reasons for this are not clear, but we suppose that $N$-acetyl-D-glucosamine was degraded by hydrolysis procedure. The ${ }^{1} \mathrm{H}$ - and ${ }^{13} \mathrm{C}-\mathrm{NMR}$ spectra of genin part in 2 were similar to that of $\mathbf{1}$, except for the downfield shift of C-3 (1: $\delta$ 68.9, 2: $\delta$ 74.0). From the analysis of ${ }^{1} \mathrm{H}-{ }^{1} \mathrm{H}$ COSY and $\mathrm{HMBC}$ correlations in $\mathbf{2}$, the genin of $\mathbf{2}$ was determined to be the same as the anthrasteroid skeleton of 1 (Figure 3a). Observation of the HMBC correlations from the anomeric proton $\left(1^{\prime}-\mathrm{H}\right)$ of D-mannose to C-23 and anomeric proton $\left(1^{\prime \prime}-\mathrm{H}\right)$ of $N$-acetyl-Dglucosamine to $\mathrm{C}-3$ in 2 suggested that the D-mannose and the $\mathrm{N}$-acetyl-D-glucosamine linked at C-23 and C-3 in the genin of 2, respectively. The glycoside linkage of $\mathrm{N}$-acetyl-D-glucosamine was determined as $\alpha$-configuration from the $J$ of the anomeric proton $\left(3.7 \mathrm{~Hz}\right.$ for $\left.1^{\prime \prime}-\mathrm{H}\right)$, and that of $\mathrm{D}$-mannose was determined as $\beta$-configuration from the NOESY correlation between $1^{\prime \prime}-\mathrm{H}$ and $5^{\prime \prime}-\mathrm{H}$ (Figure $\left.3 \mathrm{~b}\right)$.

Malsteroside C (3) was obtained as a colorless crystalline powder (m.p. $137.9^{\circ} \mathrm{C}$ from $\mathrm{MeOH}$ ): molecular formula $\mathrm{C}_{34} \mathrm{H}_{52} \mathrm{O}_{8}$ by direct ion analysis in real time-time of flight-MS $\left(\mathrm{m} / \mathrm{z}: 589.3778[\mathrm{M}+\mathrm{H}]^{+}\right.$, calculated for 589.3740); $[\alpha]_{\mathrm{D}}^{20}-33^{\circ}\left(c\right.$ 1.0, MeOH); UV $\lambda_{\max } \mathrm{nm}(\log$ $\varepsilon): 272.0$ (3.00), 246.0 (2.49), 226.0 (sh, 4.04), 214.0 (4.25); IR $v_{\max }^{\text {ATR }}$ $\mathrm{cm}^{-1}: 3280,1645,1500$. The ${ }^{1} \mathrm{H}$ - and ${ }^{13} \mathrm{C}-\mathrm{NMR}$ spectra of genin part in 3 were similar to that of $\mathbf{1}$, except for the downfield shift of C-11 (1: $\delta$ 26.7, 3: $\delta 67.7)$. From the results of MS spectra, it was clear that malsteroside $\mathrm{C}(3)$ has more than one oxygen atom than malsteroside A (1). These results revealed that the genin of 3 was 11-oxygenated of that of 1 . This was confirmed by the detail analysis of 2DINADEQUATE and HMBC spectra (Figure 4a). Acid hydrolysis of 3 gave D-mannose, which was determined by the comparison to standard compound, and analysis of 2D-INADEQUATE and NOESY spectra of 3 (Figure 4b). Observation of the NOESY correlation between methyl group of $18-\mathrm{H}_{3}$ and oxygenated methine proton of $11-\mathrm{H}$ in 3 suggested that the stereochemistry of $\mathrm{C}-11$ is ' $\mathrm{R}$ ' configuration.

Malsterosides A (1)-C (3) were tested for cytostatic activity against human malignant epithelial cells (Hela) and human lung cancer cells (A549) using a modified method. ${ }^{3}$ Malsteroside A (1) inhibited the cell proliferation of Hela and $\mathrm{A} 549$ with $\mathrm{IC}_{50}$ values of 28.1 and

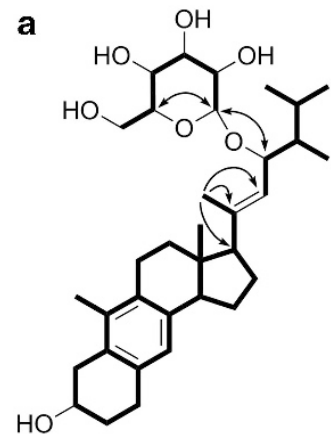

— 2D-INADEQUATE correlations

$\rightarrow$ Selected HMBC correlations

Figure 2 2D-NMR correlations of malsteroside A (1). (a) Correlations of 2DINADEQUATE and selected HMBC spectra. (b) Correlations of NOESY spectrum.

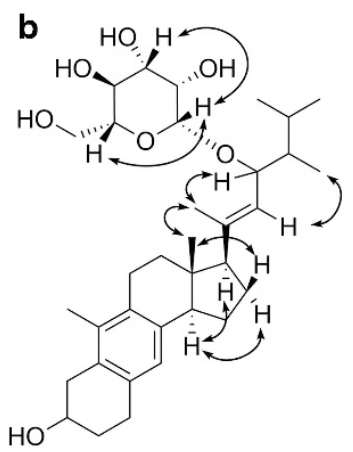

$\rightarrow$ Selected ROESY correlations

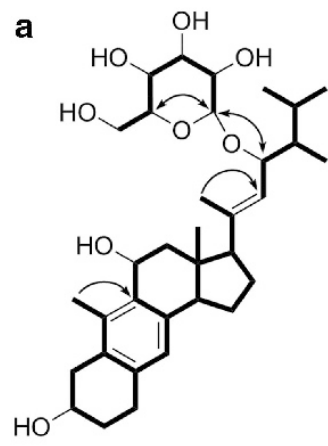

- 2D-INADEQUATE correlations

$\rightarrow$ Selected HMBC correlations

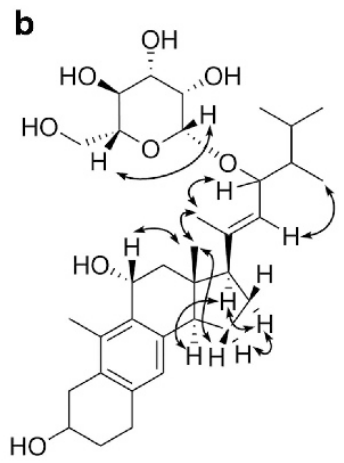

Selected NOESY correlations

Figure 4 2D-INADEQUATE and HMBC correlations of malsteroside C (3). (a) Correlations of 2D-INADEQUATE and selected HMBC spectra. (b) Selected correlations of NOESY spectrum.

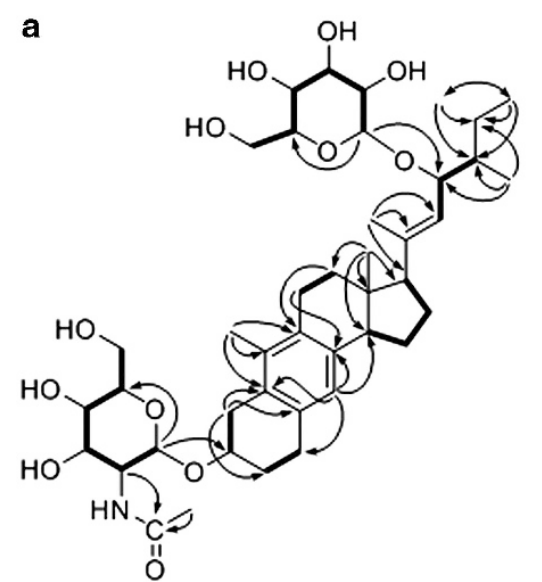

b

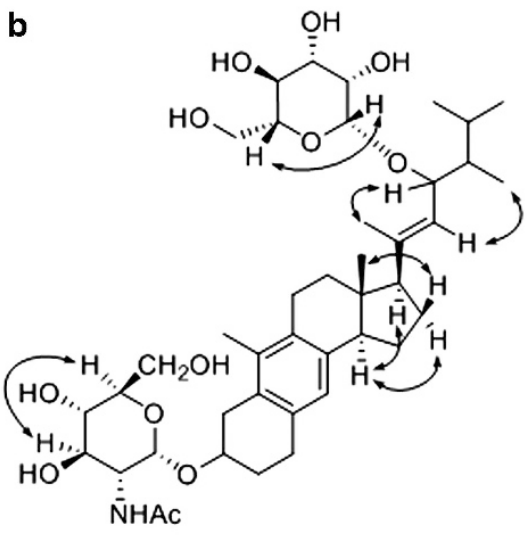

\section{$-{ }^{1} \mathrm{H}-{ }^{1} \mathrm{H}$ COSY correlations \\ $\rightarrow$ Selected HMBC correlations}

Figure 3 2D-NMR correlations of malsteroside B (2). (a) Selected correlations of ${ }^{1} \mathrm{H}-{ }^{1} \mathrm{H}$ COSY and HMBC spectra. (b) Correlations of selected NOESY spectrum. 
$38.6 \mu \mathrm{M}$, respectively. Malsteroside C (3) showed moderate cytostatic activity for Hela cell line ( $\mathrm{IC}_{50}$ value: $76.9 \mu \mathrm{M}$ ) and malsteroside B (2) showed no inhibition of these cell growths.

Compounds with anthrasteroidal skeletons are rare in nature. Isolation of anthrasteroids has been first reported by Hussler and Albrecht ${ }^{6}$ from Cretaceous black shale. Then, citreoanthrasteroids A-B from fungi ${ }^{7}$ and other anthrasteroidal structure from sheep tick ${ }^{8}$ have been isolated. From our knowledge, malsterosides A (1)-C (3) are the first examples of anthrasteroidal glycosides.

Acid hydrolysis of malsterosides A (1)-C (3) were carried out as follows. Malsterosides A (1)-C (3) (each $10 \mathrm{mg}$ ) were dissolved in $4 \mathrm{M}$ $\mathrm{HCl}(10 \mathrm{ml})$ and the solution was refluxed for $2 \mathrm{~h}$. After cooling, the reaction mixture was extracted with $\mathrm{CHCl}_{3}$ and then concentrated in vacuo. The aqueous layer obtained after extraction of reaction mixture was chromatographed using HPLC on amino column with $60 \%$ $\mathrm{CH}_{3} \mathrm{CN}$ to give D-mannose (1: $2 \mathrm{mg}, 2: 1 \mathrm{mg}$ and 3: $2 \mathrm{mg}$ ).
1 Udagawa, S. Taxonomical outline of dermatophytes in the Ascomycetes. Jpn J. Med. Mycol. 38, 1-4 (1997).

2 Hosoe, T. et al. 4-benzyl-3-phenyl-5 $\mathrm{H}$-furan-2-one, a vasodilator isolated from Malbranchea filamentosa IFM 41300. Phytochemistry 66, 2776-2779 (2005).

3 Wakana, D. et al. The cytotoxic and antifngal activities of two new sesquiterpenes, malfilanol A and B, derived from Marblanchea filamentosa. J. Antibiot. 62, 217-219 (2009).

4 Wakana, D. et al. Structures of new triterpene glycosides, malbrancheosides A-D, from Malbranchea filamentosa. Heterocycles 75, 1109-1122 (2008).

5 Wakana, D., Hosoe, T., Itabashi, T., Fukushima, K. \& Kawai, K. Structures of two new glycosides of furanone derivatives, malfilamentosides $A$ and $B$, isolated from Malbranchea filamentosa. Mycotoxins 58, 1-7 (2008).

6 Hussler, G. \& Albrecht, P. C27-C29 monoaromatic anthrasteroid hydrocarbons in Cretaceous black shales. Nature 304, 262-263 (1983).

7 Nakada, T. \& Yamamura, S. Three new metabolites of hybrid strain KO 0231, derived from Penicillium citreo-viride IFO 6200 and 4692. Tetrahedron 56, 2595-2602 (2000).

8 Saman, D, Cvacka, J., Svatos, A., Bouman, E. A. P. \& Kalinova, B. Structure identification of an anthrasteroid hydrocarbon from the Sheep tick Ixodes ricinus. J. Nat. Prod. 69, 1203-1205 (2006). 